\section{MORE ABOUT EXTINCTIONS}

Despite recent criticisms, the concept that major biological extinctions over the past $250 \mathrm{Ma}$ were periodic has now been upheld by D.M. Raup and J.J. Sepkoski (University of Chicago) in Science (21 February 1986, p. 833-836). They report new lime-series analyses that confirm eight major episodes of extinction, especially at the generic level, with a periodicity of $26 \mathrm{Ma}$.

New studies of the Cretaceouslertiary boundary in Saskatchewan have detected coincident anomalies in abundance of iridium and fern spores. D.J. Nicols (USGS, Denver), D.N. Jarzen (Ottawa, Canada) C.J. Orth and P.Q. Oliver (Los Alamos, U.S.A.) report local extinction of up to $30 \%$ of the angiosperm species across the boundary (Science, 14 February 1986, p. 714-717). What is of special interest is the persistence across the boundary of most climatically sensitive taxa. If the paleoclimate was altered by an end Cretaceous event, it may have changed only briefly, for persistence of these taxa suggests no profound and lasting climatic change.

A. Hallam (University of Birmingham, U.K.) again rises to the challenge 1.o argue that the Pliensbachian and Tithonian extinction events of the Jurassic affected marine invertebrates on regional but not global scales. He relates these extinctions to severe reductions in habitat area due to epicontinental regression or to widespread anoxia (Nature, 27 February 1986, p. 765-768).

\section{MID-CARBONIFEROUS EUSTASY} AND EXTINCTIONS

A major eustatic event $330 \mathrm{Ma}$ ago is indicated by a world-wide survey of mid-Carboniferous (Namurian) basin and shelf successions. According to W.B. Saunders (Bryn Mawr College, U.S.A.) and W.H.C. Ramsbottom (University of Sheffield, U.K.) in Geology (March 1986), the event began with a regression around 330 Ma followed by a brief transgression at $328 \mathrm{Ma}$ and a major one that flooded shelves around $325 \mathrm{Ma}$

Unconformities produced by this event separate the Mississippian and Pennsylvanian of North America and are also found in Europe, North Africa and elsewhere. They mark the new international standard for the midCarboniferous boundary (see Episodes June 1985). Biological changes at this time were profound, with many gener of ammonoids and crinoids becoming extinet and others, like foraminifera, decreasing in diversity. Why this event had such a great biological effect is not clear, but the authors suspect environmental stresses due to reduction of shelf areas.

\section{RADON AT HOME}

- Scientists in Sweden and the United Kingdom have been concerned for some time about radon emissions into homes built on granite and granitederived overburden, and now American geologists have raised a similiar danger cry. Arthur Socolow of the Pennsylvania Geological Survey pointed out recently that some homes in the U.S. may have up to 200 times the safe limit placed by the U.S. Environmental Protection Agency for radon in air.

One alarming recent prediction is that some 2,000-20,000 Americians will probably die every year from lung cancers caused by radon. Douglas Mose (George Miason University, Fairfax, VA) has begun a survey of homes in Virginia, especially in the crystalline terrane of the Reading Prong, to identify areas of high radon emission and to relate these to the underlying geology, as well as to house design and construction. The search for radon-rich soils and foundations in urban areas is clearly just beginning.

\section{ARID LANDS BY ANY OTHER NAME}

- A recent note by N. E. West (Utah State University, Logan) in Nature (5 June 1986) reminds us that the term "desertification" has become a common term to describe man-induced "impoverishment of terrestrial ecosystems," whereas "desertization" is often used for the "expansion of desert-like landforms and landscapes in arid to semi-arid environments." Thus, the degrading of tropical forests into savanna can be described as desertification.

"Aridization" has been proposed for the drying-out process, but West prefers "xerification" to describe "concommitant diminishment of vegetation and degradation of soils under unsustainable levels of land use in semi-arid areas," especially in western North America. He would now extend this term to cover soil processes related to salinization, leaving open the question of whether xerification is natural or anthropogenic.

\section{ROCK FRACTURE AND EARTH- QUAKE LIGHTS}

The study of earthquake lights, luminous phenomena associated with earthquakes but rarely recorded in an objective manner, has been given a boost by a recent report by B.T. Brady and G.A. Powell (U.S. Bureau of Mines, Denver, Colorado). They observed almost instantaneous bursts of light during experimental failure of granite and basalt specimens in uniaxial compression in various atmospheres. Spectrographical and electromagnetic analyses support an exoelectron bombardment mechanism (Nature, 29 May 1986). Although none of the experiments produced luminosity even as long as one second, compared to some earthquake lights that have been recorded for $11 / 2$ minutes, these experiments suggest the beginning of a new area of study.

CALDERAS, SHOCK DEFORMATION AND THE $\mathrm{K}$-T BOUNDARY

One of the strongest arguments in favour of an asteroid impact at the Cretaceous-Tertiary boundary is the presence of shock lamellae in quartz grains here. However, N.L. Carter (Texas A\&M University, College Station), C.B. Officer (Dartmouth College, New Hampshire) and C.A. Chesner and W.I. Rose (Michigan Technical University, Houghton) report the presence of microstructures and textures in ignimbrites from the Toba caldera deposits in Sumatra that indicate shock levels greater than 10 $\mathrm{GPa}$

These features include strong kinking in biotite and shock mosaics and possible partial melting in plagioclase. Although shock microstructures in quartz are rare, the authors argue (Geology, May 1986) that these may have been healed in the hot ignimbrite. Their "preliminary" results suggest that violent silicic volcanic explosions can produce local stress concentrations high enough to yield shock features that might otherwise be ascribed to impacts.

\section{GEOCHEMISTS ORGANIZE IN} EUROPE AND BRAZIL

Two new societies for geochemistry have emerged in the past year. The European Association for Geochemistry (EAG) was formed at the biannual meeting of the European Union of Geosciences in Strasbourg in April 1985 to "coordinate scientific meetings, organize workshops, encourage student exchanges, and support the advancement of geochemistry, particularly within Europe." The first President is A.B. Thompson (Zurich) with $Y$. Bottinga (Paris) Vice-President and D.J. Fraser (Oxford) as Secretary. Membership enquiries should be directed to M. Engi, EAG 
Treasurer, Institut für Mineralogie und Petrographie, ETH Zurich, CH-8092 Zurich, Switzerland.

In Ouro Preto recently, the Geochemical Society of Brazil (Sociedade Brasiliera de Geoquimica, SBGq) was established. With a membership now over 200, plans are underway to publish a new journal, Geochimica Brasiliensis" and to organize a geochemical congress in 1987. The first President is C.V. Dutra, Secretary-General, D.C. Bruni and the address of the society is $C P$ 2432, CEP 20010, Rio de Janeiro, Brazil.

\section{MINER AL DEVELOPMENT IN TANZANIA}

A new geology building at the University of Dar es Salaam in Tanzania was opened last December, the gift of the government of Finland, which is also providing staff, equipment and other support to 1990. A panel held at the opening ceremonies to discuss ways to revive the mineral sector of Tanzania pointed out that the only local minerals of international interest at present are precious metals, gems and hydrocarbons.

According to a report by U. Aswathanarayana, Head of the Department of Geology, "lack of foreign exchange has been recognized as the single, most serious impediment to progress." However, this has often been used as an "excuse . . to explain away inactivity, rather than spurring efforts to design alternative programs which can be pursued without much or any foreign exchange, such as digging wells, preparation of clay bricks, and geology mapping." There were references to the "economic compulsions to dovetail our mineral programs to suit the international mineral markets." The conclusion was that in the long term, training of geological manpower and basic research on Tanzania's geology and minerals should be focussed on minerals that support indigenous industries.

\section{BIF AND THE EARTH-IMOON DISTANCE IN THE PRECAMBRIAN}

Sedimentary cycles of 23.3 years' duration in a banded iron formation (BIF) $2.5 \mathrm{Ga}$ old at Weeli Wolli in the Hammersley Group of Western Australia, previously interpreted as reflecting the double sunspot cycle, are now viewed as due to the climatic influence of the lunar nodal tide. J.C.G. Walker and K.J. Zahnle (University of Michigan, Ann Arbor) calculate that the Earth-Moon distance was then about 50 Earth radii as compared to the present distance of some 60 radii (Nature, 17 April 1986). Their conclusion obviates the need for a collision between the Earth and Moon some 1.5-2.0 Ga ago commonly calculated by extrapolating the pace of tidal evolution over the past $450 \mathrm{Ma}$.

\section{ATMOSPHERIC WATER DUE TO COMETS?}

An exciting new study of satellite photometer images recorded in some 30,000 individual sightings over the last 5 years has detected transient dark spots ("holes") in the atmospheric dayglow. These dark spots reflect decreases of several minutes duration occurring at a rate of about 10 events per minute in the emission of light from the high atmosphere on the side of the Earth illuminated by the Sun.

L.A. Frank, J.B. Sigwarth and J.D. Craven (University of Iowa, Iowa City) interpret these increases in terms of an influx of hitherto undetected comet-like objects composed of fluffy aggregates of water snow or clathrate and covered with a mantle of dust (Geophysical Research Letters, April 1986).

Their average mass is estimated at about 100 tons, their speed less then $20 \mathrm{~km} / \mathrm{sec}$, and diameter around $12 \mathrm{~m}$. The accretion rate of these "comets" corresponds to a total mass influx of $10^{12} \mathrm{~kg} / \mathrm{yr}$, enough to replace the whole atmospheric mass in about 5 million years. If so, the Earth and presumably other bodies in the Solar System may be more strongly coupled to cometary matter than previously thought. Such a mechanism could help to explain phenomena like the presence of water vapour in the atmospheres of Mars and Venus, the onset of glaciation on Earth, and even the extinction of species.

\section{SEA LEVEL RISE CAN BE MANAGED}

Sea levels worldwide have been generally rising at more than $1 \mathrm{~mm} / \mathrm{yr}$ for most of this century, and the greenhouse effect is expected to add another 0.6 to $3.5 \mathrm{~m}$ by the end of the next century, primarily from the melting of ice and with devastating effects on coastal cities. What may not be generally appreciated, however, is that the storage of water in reservoirs and irrigation schemes over the last 50 years has amounted to about $375 \mathrm{~km}^{3} / \mathrm{yr}$, equivalent to a potential annual rise in sea level of $0.75 \mathrm{~m}$.

According to W.S. Newman (Queens College of the City University of New York, Flushing) and R.W. Fairbridge
(Columbia University, New York), this means that the actual sea-level rise has lagged about 26 years behind wh:t would have occurred had man not intervened in this way. They propose (Nature, 27 Narch 1986) that further anthropogenic management of sea level rise could be accomplished by channeling sea water into interior basins that lie below the present sea level, for example the Qattara Depression of northeastern Egypt, the Imperial Valley of California, the Salina Gaulicho of Argentina, and the Aral-Caspian Depression of the U.S.S.R.

Despite the obvious difficulties and possible side effects (on ocean dynamics, geochemistry, climate etc.), the authors argue that "to prevent worldwide littoral disaster, new projects must be planned immediately and be well under way by the end of this century... Sea level rise joins 'death and taxes' as the inexorable fate of mankind."

\section{INTR APLATE STRAIN IN THE} EASTERN U.S.A.

Repeated measurements by very long baseline interferometry have now shown a convergence rate between northeastern Massachusetts and southwestern Texas of $1.2 \mathrm{~cm} / \mathrm{yr}$, indicating a strain rate of $10^{-16}$ per second. In a presentation to the American Geophysical Union spring meeting on May 20, 1986, S.A. Musman (National Geodetic Survey, Atlanta, GA) and T. Schmidt (Georgia Geological Survey, Atlanta) commented that though this may seem high for a stable continental interior, it is supported by rheological and depth models for the lithosphere and by the observed seismicity in the eastern U.S.A.

\section{BENTONITE IMPROVES EDIBLE OILS}

An intriguing study has been reported of the application of montmorillonite-rich clays to peanut oil in order to reduce its aflatoxin content, while maintaining its "fragrant smell." He Liqiong (Fujian Bureau of Geology and Mineral Resources) and Huang Weiguo (Geological Party of West Fujian) also added high quality acidic clay from the Wuping mine of Fujian Province, China, to rape and rice bran oils to cause a decolouration by adsorbtion at 90 to 100 degrees centigrade, and the elimination of bothersome smells. The method is cheap, safe and reliable (Geology of Fujian, vol. 5 p. 12-32, 1986). 


\title{
Kail's Geophysical PROJEGTOR
}
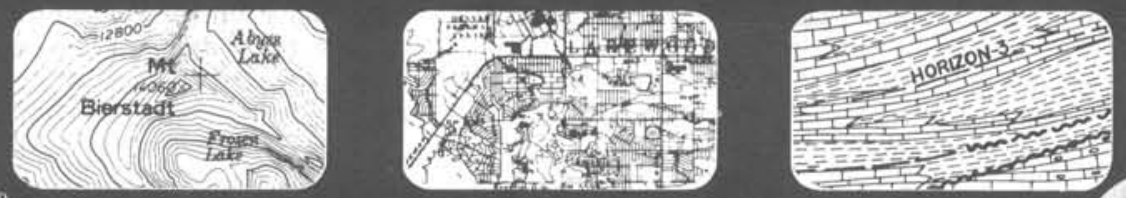

Enlarge or Reduce opaque images by automatic focusing

The Model K-A5 Reflecting Projector, ideal for mapping, aerial photography, drawings, layouts and seismic studies. Projector enclosed to form a seismic studies. Projector enclosed to form a table transposed from lane glass plane to the other with transposed from one glass plane

- Image in focus in entire scale range

- Scale from $5 x$ to $1 / 5 x$

- Reflects opaque materials to translucent papers

- Single automatic focus

- Dimensions $80^{\prime \prime}$ long. $30^{\circ}$ wide, $36^{\prime \prime}$ high

Philip B. Kail Associates, Inc.

1010 West 1st Avenue

Denver, Colorado 80223

(303) 623-5987

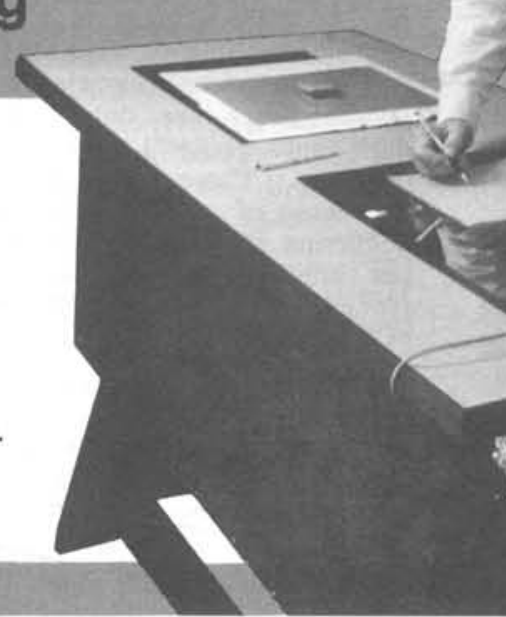

\section{CANADIAN SOCIETY OF PETROLEUM GEOLOGISTS}

\author{
CALGARY, ALBERTA
}

\section{MEMOIR SERIES}

Hard cover volumes encompassing specific topics and themes of global significance.

MEM 2. The Permian and Triassic Systems and their mutual boundary Eds, A Logan and L.V. Hills, 1973. 765 p., 51 contributions, a penetrating global consideration of the topic. Canada \$25.00; International $\$ 29.00$

MEM. 3- Oil sands - fuel of the future. Ed. L.V. Hills, 1974, 263 p., 19 papers, an indispensable book for those needing to know about the world's oil sands.

Canada \$12.60; International $\$ 14.00$

MEM. 5. Fluvial sedimentology. Ed. A.D. Miall, 1978. 850 p., 41 papers by authors from seven countries. First of its kind ever published. Into its second printing.

Canada \$36.00; International $\$ 39.00$

MEM. 6. Facts and principles of world petroleum occurrences. Ed. A.D. Miall, 1980. 1003 p. Origin of petroleum accumulations and case histories from around the world.

Canada \$41.00; International \$44.00

MEM. 7. Geology of the North Atlantic borderlands, Eds. J.W. Kerr and A.J. Fergusson, 1981 743 p. Precambrian to Modern framework of American and European borderlands.

Canada \$36.00; International $\$ 39.00$

MEM, 8- Arctic geology and geophysics. Eds. A.F. Embry and H.R. Balkwill, 1982.552 p Precambrian to Tertiary geology from Barents Sea to Alaska. Proceedings of the 3 rd International Symposium on Arctic Geology

Canada $\$ 36.00$; International $\$ 39.00$

MEM. 9. The Mesozoic of Middle North America. Eds. D.F. Stott and D.J. Glass, 1984. 573 p. Mesozoic geology from the Beaufort Sea, Canada southward to San Juan Basin, U S.A.

Canada \$35.00; International \$38.00

MEM. 10 - Sedimentology of Gravels and Conglomerates. Eds. E.H. Koster and R.J. Steel, 1984. $441 \mathrm{p}$. A comprehensive treatise on the subject. Papers from the $11^{\text {th }}$ International Congress on Sedimentology.

Canada $\$ 35.00$; International $\$ 38.00$

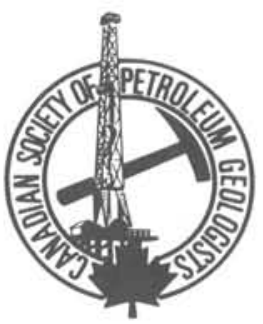

Prices in Canadian funds includes mailing and handling.

Please send money with order or supply VISA card number and expiry date.

Send order to: Canadian Society of Petroleum Geologists \#505,206-7th Avenue S.W. Calgary, Alberta Canada T2P OW7 